\title{
Integrated Value Configurations in the Sharing Economy
}

\author{
Andreas J. Reuschl \\ University of Bayreuth \\ andreas.reuschl@uni- \\ bayreuth.de
}

\author{
Ricarda B. Bouncken \\ University of Bayreuth \\ bouncken@uni-bayreuth.de
}

\author{
Sven M. Laudien \\ University of Erfurt \\ sven.laudien@uni-erfurt.de
}

\begin{abstract}
Sharing has become a new trend in business that heavily affects the ways how firms do business. Despite this important development, research by now only provides rudimentary insights into value configuration mechanisms applied in the sharing economy. Our paper that is inspired by extant research on value creation configurations as well as recent business model research develops a model of an integrated value network for the sharing economy. We explain that focal firms in sharing economy networks ground their business model configuration in the application of web-based technology. We further point to two dimensions that determine the positioning of the business model: the degree of individualization vs. standardization of the content and the degree of completeness of property rights.
\end{abstract}

\section{Introduction}

Sharing has become an important issue in today's economy leading to a need for restructuring value creation, value delivery, and value capture activities. Researchers recently try to better understand and adequately mirror the phenomenon of the sharing economy which is continuously growing in scale and scope [1-5]. The sharing economy comprises all activities related to sharing or granting access to goods and services among peers [1]. Interestingly, sharing seems to provide greater value for customers in utilizing products or services compared to ownership $[3,5,6]$. So far, scholars concentrated on mentioning successful cases of sharing economy business models. For example, Airbnb as becoming largest provider of accommodation without owning a single hotel or apartment building [2]. Uber is unsettling the taxi industry without owning a single vehicle. Several firms are following the sharing trend by starting models for e.g. sharing cars [6-8], sharing accommodation [9], sharing wifi-connection, computers, services like child care, and even sharing food [5]. The recent advancements in ICT provide the groundwork for these newly developing business models as they allow for an easy connection between key partners [5].

Nonetheless, we still lack an understanding of value creation, value delivery, and value capture configurations that determine sharing economy business models on in business-to-consumer (B2C) and also business-to-business (B2B) settings. Apple or Dell, for example, already forgo the acquisition of production facilities and rather 'buy access' to the production capacities of Foxconn [10]. The emerging (Industrial) Internet of Things that is characterized by an in-depth connection of machines, processes, and production facilities with internet-based applications that offers several opportunities for creating sharingbased business models [11, 12]. The (Industrial) Internet of Things digitally accesses machines and production facilities, allowing their integration into sharing economy business models $[5,6]$. However, previous research does only partially provide information about business models in the sharing economy $[3,5,8]$. We lack a distinct framework for generic strategic paradigms such as theory of the competitive advantage [13] or the resource based view of the firm [14] which cannot explain the constitutive role of web-based technology that configures and coordinates value creation, value delivery, and value capture in the sharing economy. New approaches modelling value configuration are needed for the sharing economy.

Therefore, we aim at understanding different ways of value creation, delivery, and capture that have emerged in the context of the sharing economy. We develop a model of an integrated value network that may serve as blueprint for sharing economy business models. Our results assist managers in achieving and intensifying the proclaimed advantages of the sharing economy.

Our model builds upon ideas of the value creation framework of Stabell and Fjeldstad [15], extending it through insights of the internet economy [16], as well 
as developing it towards the sharing economy by applying the business model approach [17]. We draw upon case examples for better understanding of the sharing economy. Our model of an integrated value network is constituted by an information system technology that builds the kernel of the value configuration that relies on and combines different activities within a focal firm and its network [18]. Activities relate to the combination of virtual and real goods or virtual solutions for the shared use of real goods [17]. Using the case examples on the content, the structure of the business model and its governance, we find two dimensions of the integrated network: One dimension is the degree of standardization vs. individualization of the content. The second dimension refers to the control of real goods. If a focal firm owns the goods fully respectively has more complete property rights is can better define the usage, change, coordination, and design of the good. With complete property rights the focal firm in the value network which does not have to consider the interest of other owners in their sharing economy business model. Instead, more particularized ownership respectively fewer property rights might force the focal firm considering the interests of several private owners, who might have socio-emotional interests that require adaptations of the positioning and technical system. We portray different examples of sharing economy business models along the two dimensions, providing additional guidance for managers and integrated system solutions.

\section{Theory background}

\subsection{Sharing Economy}

Researchers describe the sharing economy as "peer-to-peer-based activit[y]ies of obtaining, giving, or sharing the access to goods and services, coordinated through community-based online services" $[1, p .1]$. The sharing economy comprises all forms of sharing activities organized as web-based interactions $[1,5]$. Similar approaches like the digital economy are still vague concepts “(...) about dynamics, not static efficiency (...), about new activities and products [rather] than about higher productivity." [19, p. 246]. Hamari, Sjöklint [1] emphasize the importance of ICT in the sharing economy. The sharing economy provides a higher (perceived) value of goods and services as they are immediately and directly made available for customers at the point in time when they are needed a process, that is intensively supported by web-based solutions [5]. The web-based connectivity enables consumers to connect, to exchange information, and to coordinate sharing activities which results in the development of innovative business models that are new to the market [20]. Pohjola [21] concludes that the worldwide web integrates markets, links market participants across boundaries, and contributes to the emergence of globally unified markets. The concept of collaborative consumption of goods and services in the sharing economy [3] changes consumers' attitude towards property and ownership. Belk [5] argues that the web facilitates sharing unused assets with partners to maximize the utility these assets generate. This leads to a collaborative consumption with "people coordinating the acquisition and distribution of a resource for a fee or other compensation" [5, p. 1597]. The consequence is dramatic: Customers and consumers lose interest in ownership or long-term property rights and focus on distinct access rights that allow to make use of goods and services only for the limited time span when their utilization is necessary $[3,5,6]$. This trend impacts $\mathrm{B} 2 \mathrm{C}$ relations and $\mathrm{B} 2 \mathrm{~B}$ relations as especially ongoing technical improvements allow to 'share' production capacities and thus to integrate production capacities into sharing systems [5, 11, 12]. Taking upon these potentials requires an understanding how value is created, delivered, and captured in the sharing economy.

\subsection{Three creation models by Stabell and Fjeldstad (1998)}

Two very dominant paradigms in strategic management research are the competitive strategy framework drawing upon Porter (i.e. [22, 23]) and the resource based view of the firm [14, 24, 25]. Both opposite perspectives offer well-accepted generic explanations for firms' success but insufficiently specific answers for explaining how firms create, deliver, and capture value in the sharing economy. Stabell and Fjeldstad [15] investigated value creation in at time of the first era of e-commerce, specifically considering technologies and network relations. Firms can follow three distinct models of value creation the value chain as proposed by Porter, the value shop that deploys technology and know-how to solve individual clients' problems, and the value network that offers network services [15].

The value chain explains firms as systems that transform input into output. Value chains apply longlinked technologies that allow a sequential process driven production [15, 26]. Rayport and Sviokla [27] used the music industry to illustrate firms' competition in the "real" world and in the worldwide web. Firms integrate digital value adding functions into their value 
chain to increase the transparency of real processes in the virtual environment (visibility), to exchange real processes through virtual ones (mirroring capabilities), and to establish new customer relationships. However, online value creation differs from the linear value chain as it needs non-linear activities of gathering, organizing, selecting, synthesizing, and distributing information [27]. Laffey [28] introduced a click chain to explain digital value creation based on a case study of a financial comparison website. The primary activities are replaced by inbound clicks (visitors to the website), operations (matching users and products), outbound clicks (transfer of visitors to product providers), marketing and sales (marketing for users and product providers), and services. This model recognizes the digital value creation through information flows of comparison websites. Yet, value configurations in the sharing economy are not fully based upon a sequential value chain model where value is added by longlinked technologies.

The configuration value shop comprises individualized one-to-one services by experts. Firms organized as value shops typically try to solve nonlinear problems for customers as by architects, consultants, or e.g. medical services. Value shops first have to identify problems, solve these problems (generate alternative solutions), choose a solution (decision between alternative solutions), execute the solution (solution implementation), and control and evaluate the results (control implementation success). Value shops rely on intensive technologies (customized combination of resources, capabilities, and technology) for their primary activities [15, 26]. Thus, the value shop falls short in explaining both the standardized and individualized customized servicegoods- combination over the internet and via IT.

Value networks concentrate on mediating capabilities between the single levels of a supply chain (vertical) or the mediating capabilities between customers and e.g. other networks. The primary activities of value networks consist of network promotion and contract management (managing networks and fees), service provisioning (managing the links between participants), and network infrastructure operation (hardware maintenance). Examples are telephone firms, retail banks, and postal services. Following Thompson [26], Stabell and Fjeldstad [15] highlight mediating technologies for value networks which enable links between customers, organizations, and further actors.

Yet, the sharing economy uses not only a vertical, but also horizontal integration which is fundamentally constituted by (IT-)technology. IT has a central role for creating, coordinating, and constituting the structure of a business model. The limited understanding of value configuration in the sharing economy with its core web-based technologies, the network of partners, and the different activities by diverse providers, possibly as a specific value layer or platform of its own can take upon a new approach in management, the business model innovation [29].

\subsection{Business model innovation}

At the outset of e-commerce, researchers have proposed that future strategic management will be about business models [29-31]. BM and their innovation stem from the creation and capture of value from the combination of activities (e.g. IT and operations) into solutions, which can be products and services, and models how to capture and protect the value of, specifically when acting within a network [32]. Business model innovation (BMI) raised interest in research as well as business practice [33]. BMI is often associated with radically new business models that foster growth as well as the emergence of a competitive advantage [29]. Researchers very often employ an activity-based perspective departing from the definition that a business model is ".... a system of interdependent activities that transcends the focal firm and spans its boundaries.' [34, p. 216] and focusing on an analysis of new value creation logics [35]. BM and their innovation build on a combination of activities among firms in a network and away from the focus on product (innovation) and their best strategic positioning and pricing to achieve a competitive advantage [36]. According to Amit and Zott [29, 30, 36] a business model is a combination of the three design elements content, structure, and governance [37]. Content depicts the activities that are performed within the activity system. It includes the exchange of products, services, and information between the various network partners as well as the capabilities required to enable this exchange. Structure aims at the linkages and the sequencing of the system's activities. Network size or the flexibility and adaptability of the system fall into this context. Governance describes by whom the activities are performed as well as the locus and nature of control of transactions within the activity system.

BMI is the result of novel combinations of activities that allow for ways of value creation, delivery, and capture that are new to the market [38]. BMI can even take place under conditions of resource scarcity as it does not necessarily require new resources [35] - an aspect that deserves attention in the context of our research setting as it contradicts the traditional resource-based view. New ways of creating value become manifest in new products or services. 
Value delivery is innovated when the firm introduces new ways of bringing the value to the customer (e.g. offline content vs. online content) as part of the business model. Value capture comes from employing e.g. membership fees or a transaction-based payment model rather than traditional product- or service-based payment models. Activities go beyond the mere use of technologies [39] and cross the boundaries of single firms, being often embedded in networks and using the internet [30]. Thus, the business model approach is well suited for explaining value creation in the sharing economy.

\section{Empirical proceeding}

As we approach a by now widely unexplored phenomenon and look for in-depth insights, a qualitative way of proceeding is suitable [40]. Our research approach focuses on theory building and is inductive in nature as we do not make use of predefined propositions derived from literature (as e.g. suggested by Yin [41]), but let the data itself speak.

Table 1. Case-examples

\begin{tabular}{|c|c|c|}
\hline Case firm & Year & Description \\
\hline Airbnb & 2008 & $\begin{array}{l}\text { Peer-to-peer network that enables users to share } \\
\text { their accommodation. }\end{array}$ \\
\hline Car2Go & 2008 & $\begin{array}{l}\text { Car2Go (Daimler AG) offers a car sharing } \\
\text { network with cars from Smart and Mercedes }\end{array}$ \\
\hline $\begin{array}{l}\text { Drive- } \\
\text { Now }\end{array}$ & 2011 & $\begin{array}{l}\text { DriveNow (Sixt AG, BMW AG) offers a car } \\
\text { sharing network with cars from BMW and Mini. }\end{array}$ \\
\hline Enterprise & 1957 & $\begin{array}{l}\text { Enterprise was founded in the USA and is the } \\
\text { largest american car rental company. }\end{array}$ \\
\hline Europcar & 1949 & $\begin{array}{l}\text { Europcar was founded in France and is a major } \\
\text { European car rental company. }\end{array}$ \\
\hline Flinkster & 2009 & $\begin{array}{l}\text { Flinkster belongs to the German railway company } \\
\text { Deutsche Bahn and offers car sharing. }\end{array}$ \\
\hline Fon & 2005 & $\begin{array}{l}\text { Fon operates a sharing economy approach for } \\
\text { wifi-networks. }\end{array}$ \\
\hline $\begin{array}{l}\text { Get- } \\
\text { around }\end{array}$ & 2009 & $\begin{array}{l}\text { Getaround provides a peer-2-peer car sharing } \\
\text { network. }\end{array}$ \\
\hline $\begin{array}{l}\text { Green- } \\
\text { Wheels }\end{array}$ & 1995 & $\begin{array}{l}\text { Greenwheels is the largest car sharing network in } \\
\text { the Netherlands. }\end{array}$ \\
\hline Hapimag & 1963 & $\begin{array}{l}\text { Members of Hapimag are shareholders, invest in } \\
\text { vacation properties and are entitled to use these. }\end{array}$ \\
\hline HILTI & 1941 & $\begin{array}{l}\text { The Hilti AG is a premium manufacturer for } \\
\text { tools. Hilti also offers a tool rental model. }\end{array}$ \\
\hline $\begin{array}{l}\text { Lending- } \\
\text { Club }\end{array}$ & 2006 & $\begin{array}{l}\text { LendingClub is a US-based peer-to-peer money } \\
\text { lending network. }\end{array}$ \\
\hline $\begin{array}{l}\text { My- } \\
\text { Hammer }\end{array}$ & 1999 & $\begin{array}{l}\text { Myhammer offers an online network that } \\
\text { mediates (handicraft) services. }\end{array}$ \\
\hline Turo & 2009 & $\begin{array}{l}\text { Turo (formerly RelayRides) provides a peer-2- } \\
\text { peer car sharing network. }\end{array}$ \\
\hline Sixt & 1912 & $\begin{array}{l}\text { Sixt was founded in Germany and is a major } \\
\text { European car rental company. }\end{array}$ \\
\hline $\begin{array}{l}\text { Task- } \\
\text { Rabbit }\end{array}$ & 2008 & $\begin{array}{l}\text { TaskRabbit offers a network for all kinds of } \\
\text { services on-demand. }\end{array}$ \\
\hline UBER & 2009 & $\begin{array}{l}\text { Uber offers an application for a peer-to-peer } \\
\text { network for taxi services. }\end{array}$ \\
\hline Zaarly & 2011 & $\begin{array}{l}\text { Zaarly provides a network where users create } \\
\text { own stores and offer goods or services to users. }\end{array}$ \\
\hline
\end{tabular}

Following case study literature [40, 42] we selected 18 case firms. To ensure that the cases match our research focus, we applied specific selection criteria for the case firms: (1) all case firms are part of the sharing economy and employ business models that are based on the idea of sharing -checked by looking at the webpages of the firms. (2) Our sample is not limited to a specific group of firms (e.g. service firms) as the idea of sharing seems to be of relevance irrespective of the nature of firm offerings. (3) We excluded firms that do not conduct market operations on a regular base and non-profit firms because value creation then follows different principles.

Our main data source is archival data as we needed to draw a holistic picture of the firm and had to take into account variations of value creation strategies over time that influence the design of the business model. We collected firm-internal data (e.g. information provided on webpages or in annual reports) as well as data from external sources such as press coverage. In case of missing information, we contacted the firms and conducted several telephonebased open interviews that we carefully recorded and transcribed. A short overview over the case firms is given in table 1.

Following suggestions by literature $[42,43]$ applied an iterative data analysis process. In a first step, we created write-ups for each individual case to condense the available data. These write-ups were analyzed based on a strict coding procedure. In a second step, we compared the individual case results conducting a cross-case analysis. In doing so, we followed suggestions by case study literature [42]. The emerging categories are presented in the results part of our paper. The highly iterative process of analyzing case data was carried out independently by two researchers to enhance rigidity and to ensure consistency of our findings.

\section{Integrated Value Network in the Sharing Economy}

\subsection{Basic understanding}

From the theoretical and empirical background presented above we develop the concept of an integrated value network for the sharing economy. The sharing economy is basically about creating and maintaining networks. The term network relates to two aspects, (1) the actors in this economy, and (2) the technological linkages within the network. Both networks are first of all coordinated and integrated by web-based technologies. Further, integration means that networks do not operate on a free flow of virtual information without limitations in scale and scope. 
The integrated networks in the sharing economy are formed to support the distribution of real physical goods, such as cars, houses, or devices. Therefore, focal firms providing real shared goods face stronger coordination needs than only providing information. In contrast to physical goods, information is easily transferable, does not outwear by use, and can move with high speed through virtual environments. Thus, the sharing economy requires the combination of activities within and among firms, and as such integration activities within the network, mainly coordinated by IT and by an internet based platform.

Constituted through the information technology over the web, integrated value networks produce, coordinate and/or offer goods and/or services in networks. Firms combine these activities at different intensities internally or externally. A firm may decide to only build cars, sell them to sharing communities, and organize car maintenance - a way of proceeding that is characteristic for Volkswagen. The firm might also establish a sharing community of its own and operate this sharing community an approach Daimler and BMW have set into practice by establishing car sharing providers such as DriveNow (BMW) and car2go (Daimler). A firm might even almost fully combine all activities in the integrated network for the dominant coordination of a user network and control over value creation, delivery, and capture. Integrated value networks can also include several partners contributing complementary goods or services while extending the activity base, the customer base, more generally by increasing heterogeneity - a way of proceeding we see related to car sharing in case of flinkster, the car sharing provider of Deutsche Bahn that was introduced to provide a service for customers that allows them to easily reach places that are not integrated into the German railway system. Flinkster is remarkable as it is a role model for sharing economy business models that considerably extend the scope of action of firms by providing the opportunity to access new markets and customers.

Some firms such as DriveNow or Car2Go use social networks to access their customer base, to create lock-in effects, or to improve marketing. A horizontal integration offers additional synergetic advantages. For example, embedding car sharing communities in or connecting them with social networks can optimize occupancy, create marketing effects, or facilitate the development of additional services. Besides vertical and horizontal integration, value networks can take upon real innovation ecosystems. The sharing economy is about communication, information, or digital media networking and further on the cocreation, co-ownership, and co-utilization of goods and services in the reality. In contrast to digital media, real goods like cars have fewer utilization possibilities and cannot be transferred from one user to another without coordination cost and a physical base. Services can be delivered only once at a time by a single provider. Drawing on Stabell and Fjeldstad [15] we develop drivers for value configurations.

Optimum. The sharing economy can take upon positive externalities of value networks as outset by Stabell and Fjeldstad [15]: The value of the network for its users increases with every additional user who joins the network - as long as the additional user is not only a passive recipient of value, but actively contributes to value creation. For car sharing, more users are not beneficial as they can cause drawbacks for existing users in terms of availability of cars and in a second step maybe also prices for cars. Platforms such as Airbnb (accommodation) or MyHammer (craft), more users or members will enhance the value of the network as each new participant brings in new resources into the sharing network. The sharing economy is not only on virtual goods but on real goods and services and goods at the same time. It provides real goods and services too. Thus, sharing communities will have an optimal size.

Capacity utilization. Firms in the sharing economy need to own or integrate other owners of physical goods and provide a system of networked transaction possibilities. Car sharing providers, for example, need a sufficiently size of the user network to secure profitability which is small enough to guarantee availability - this builds a challenge for car sharing providers as their profitability is still rather very low. The network should allow a constant utilization of the cars. Once a firm reaches the critical scale and composition of its network, the capacity utilization is critical for earnings and cost reduction. Thus, the optimum network size refers to the average frequency of usage of cars and not to peak times. In other words: sharing economy networks have consider serving all customers who are willing to pay for their service.

Learning. With increasing speed of innovation and shortening product lifecycles integrated value networks' ability to learn and adapt to new developments regarding technology, demands, and e.g. regulations is crucial. As users do not buy products, they can easily change service providers. Firms constantly need to integrate new trends. It gives the opportunity for new - late - market entrants offering the most recent technology. This contradicts the ideas of generic strategies as we do not necessarily see a disadvantage for late movers in the sharing economy.

Quality. As the web offers easy information access and comparison possibilities we see quality as an important feature that influences the competitive 
position. The understanding of quality in the context of the sharing economy becomes bigger. Besides traditional criteria (e.g. performance, speed of processing, data security) the uptime of services, and uniqueness are important for standardized goods. Sustainability is another driver for the sharing economy [1]. Firms starting to participate in the sharing economy should consider this trend and take sustainability as a dimension of quality into account.

\subsection{Content as specific feature of sharing economy business models}

Sharing economy business models can like all other business models first of all be characterized by their content $[30,34]$. The content of activity systems represents the selection of specific goods or services. Surprisingly, sharing economy BM do not necessarily offer a completely new content, they very often only make content more flexible or more detailed than established BM. New content can also base on new IT solutions (e.g. augmented reality) for firms' standard operations or physical equipment. Content is very often less standardized - have in mind an apartment your rent via Airbnb - than it is the case related to traditional business models (e.g. hotel rooms of one hotel group such as Westin \& Marriott or Penta normally look very much alike). The content design applies to the ongoing trend for individualization. Sharing economy business models can bring customized solutions, especially when they combine services and physical goods.

\subsection{Constituting technology as key structural design element}

The structure element of the BM is crucial for sharing economy business models as linking the different partners and network participants calls for an exaggerate utilization of technological solutions. Activities might be provided by the firm itself and thus to a large proportion linked internally or combined within a network of firms, needing more linkages to other firms in the network. Our cases show that firms in integrated networks of the sharing economy need integration mechanisms that link the digital value proposition in networks with their products and services in the real world. Value is created through the integration of real and virtual networks, merging digital demand with physical offers. Large car sharing networks (car2go, DriveNow) rely on a digital activity system that enables the availability of 'real' cars at the right time, at the right place, in the right quality, for all demanding customers. The availability of technology determines the network size these firms can handle. Going back to the start of car sharing as community based, locally centered idea in the early 1970s, the necessity to exchange the car, keys, documents, and a paper-based booking system made it impossible for strangers to participate in the community. People needed to know each other - an aspect that has been erased by modern ICT. Accommodation sharing networks also rely on effective digital systems that enhance the availability and facilitate the booking transactions for housing possibilities - without such a support it would for example be impossible to link customers and owners of private accommodation on Airbnb. Only if the integration of digital networks in real ecosystems is successful, integrated value networks can achieve competitive advantages. However, the real world offers only limited space for the positioning of products and services.

Chesbourgh [39] puts technology at the core of a business model but claims that a business model always goes beyond the pure technology because technology has to be combined with other technologies or with other operations to bring a value for others, particularly customers. Thus, IT can build elements of a technology or connect technology and operations. Thompson [26] differentiates long-linked (sequential transformation of inputs into outputs), intensive (technology and techniques to resolve unique problems), and mediating technologies (technology and techniques to facilitate exchange between customers). However, technologies linking customers converged or lost importance in the past decades while the world wide web evolved as a focal technology to link individuals, firms, and institutions. The web enables telephoning, mailing, and e.g. processing financial transactions. Further, it creates a digital market place that integrates customers and firms regardless of time and space. Some firms specialize in providing and maintaining technical internet infrastructures, but all firms can access the internet. Mediating technology cannot explain the constituting and coordinating role of internet technology to produce services and products while linking actors at the same time. Success of firms like Uber or Airbnb does not reside (only) because they link customers, but in their ability to constitute, administer, and coordinate a network of self-linking individuals. Amazon is, for example, not only about logistics and product variety, but constituting, administrating and coordinating customer networks that engage in evaluating products. Facebook is not only mediating between users, but offering a network services that facilitate and regulate the exchanges and interaction between customers. The web allows customers to access information easily, to form 
(temporary) networks independently, and to solve problems in a collaboratively. Thus, constituting, administrating, and coordinating technologies refer to spaces, platforms, and services that provide a structuring element for self-linking evolutionary communities.

\subsection{Governance framing interaction}

All these technology-enabled interactions call for coordination and control leading to governance [34], which determines who carries out certain activities. Governance has many faces, one is the regulation of participation and responsibility. For example, the sharing economy demands regulations about who is in charge of maintenance activities or activities that are necessary to enhance as well as preserve the value of the shared good. Insufficient governance, especially about maintenance and design of the physical good might cause network problems or network dissolution. Our case studies indicate that centralized and more formal governance by the focal firm has a dominant coordination function in integrated value networks. Yet, centralized governance should enable selfregulated coordination among users. Thus, informal governance - the decentralized and self-regulated coordination among users - stands on the shoulders of formal governance and builds additional value

\subsection{Dimensions for Value Configuration}

Strategic value positioning in the sharing economy goes beyond the strategic product positioning in the old economy of classic strategic framework by Porter [13] in which products are owned by a firm. In the sharing economy, real products and services might be owned by diverse actors. We even have not only B2C or $\mathrm{B} 2 \mathrm{~B}$ relations but $\mathrm{C} 2 \mathrm{~B} 2 \mathrm{~B}$ relations in the sharing economy when providers of the goods are private 'customers'. These set several possibilities for standardizing or individualizing the content and for controlling and coordination of actors that have diverse, social-emotional targets besides economic ones. Still the focal firm of the integrated value network needs to position itself to other firms or integrated value networks or might develop different value propositions using different ownership models or strategic positioning. We argue that the sharing economy provides several possibilities for positioning their business model. We assume that core specific dimensions for positioning relate to the content and the completeness of property rights in the sharing economy business model.
Standardization vs. Individualization. Our cases show that shared goods can be highly standardized as it is e.g. the case for the offerings of Car2Go. Special standardized models that are developed around a set of solutions define the portfolio of offerings. Users follow standardized expectations which determine their perception of utility. Using shared cars is characterized by the user's low emotional involvement. Users do not aim to own the car and are not interested in individualizing it. In contrast to that, shared goods can be very individualized allowing for a special emotional experience with the goods. Airbnb, for example, provides very individualized accommodation. The specific interior or the social relations with the provider of the accommodation can provide special and even unique experiences. This individualized experience is one key selling argument for the solution. To allow greater individualization, the focal sharing economy firm - in this case Airbnb - has to provide various selection criteria for a goal-oriented choice. The unstandardized solution also demands more trust building and providing access to feedback from users. Thus, sharing economy firms that offer unstandardized goods such as Airbnb require a more detailed and complicated information technology.

Completeness of property rights. Business models in integrated networks cover the question who performs which activities [34] - a question that touches the governance aspect. Naturally, some activities have to be performed by the focal firm, but other activities are carried out by network partners or by the consumer as a co-producer of value. Our cases show that the governance structure goes beyond the mere question who does what. It also covers questions of property rights and control - aspects that influence who in the network is able to use, change as well as capture and guard value from the goods. Using, organizing, controlling, controlling, and designing the sharing of real goods, the completeness of property rights calls for attention. The focal firm may own the physical goods or diverse individual owners might share them. Even when not owning the good fully, focal firms can through property rights (e.g. stated through contracts) be able to define and control the design and shape of the goods. This completeness has major implications about how goods are maintained, organized and how they look like and function. Completeness of property rights has effects on long time use and interests. Incomplete property rights of focal firms and particularized ownership of the goods increase the possibly that private owners might share goods, but will not be interested in the economic returns only, but also in socio-emotional issues and have not only rational evaluations of spoils from misuse. Furthermore, private owners might care about social- 
emotional conflicts with users that affect their willingness to share their property and interact with users. We see in our cases that ownership is a key dimension of the strategic value positioning in the sharing economy. At the extreme, a focal firm fully owns the goods respectively has complete property rights of the goods allowing for maximal rigor of influence. In this case, the firm does not need to consider the interest of other owners when coordinating and designing goods. At the other extreme, the focal firm may only be a facilitator of the shared goods. In this case, other influence factors such as specific business logics and socio-emotional interests of private persons need consideration. Thus, a particularized ownership with incomplete property rights of the focal firm demands different coordination and control. Thus, a firm in the sharing economy demands more complicated interaction systems and governance solutions to deal with multiple motives and multi-ownership. The focal firm needs to integrate them into their constituting technology.

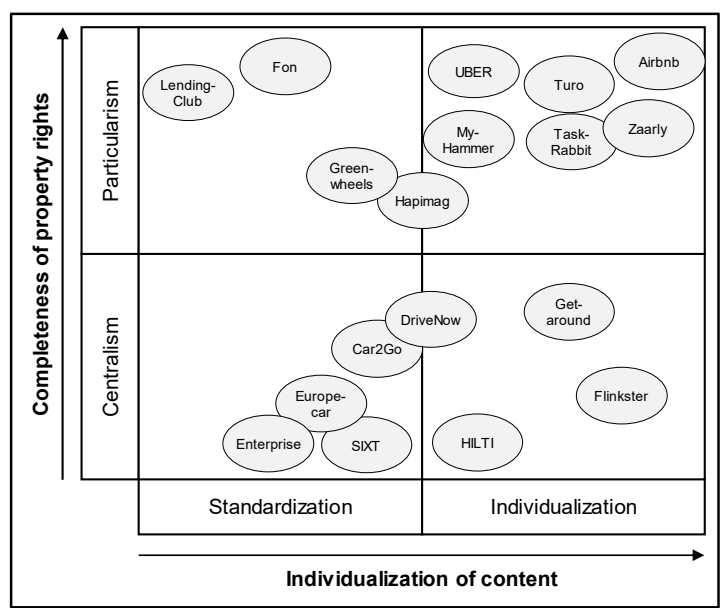

Figure 1. Dimensions for value configuration

The positioning of a sharing economy firm thus follows a two dimensional framework along the dimensions completeness of property rights and individualization vs. standardization of content. Figure 1 gives an overview over the positioning of our case firms in this framework.

Car rentals like Europcar, Sixt, or Enterprise completely own the property rights of their standard products, and allow customers to use vehicles for a fee. Individualization is only possible in terms of renting additional services or cars with predefined features. LendingClub organizes a peer-to-peer network that allows members granting and obtaining loans. This illustrates an integrated value network where individuals (high particularism) own and give temporal property rights for a highly standardized content (money). Similarly, Fon organizes a great amount of individuals that participate in sharing the standardized content 'access to wifi' among members the members of network who retain the property rights over their wifi access (high particularism). Airbnb serves as perfect example for integrated value networks where individuals contribute their individualized content to network without transferring property rights. Airbnb provides a constituting technology that allows members of the network to initiate contacts, do business, and to secure transactions. Thus, Airbnb achieves a position where highly individualized content of a huge variety of users is integrated into a network that creates values. Zaarly and TaskRabbit also strive to achieve such a position. They provide networks where individuals may offer or demand any kind of services and goods for or from other members. Zaarly and Task-Rabbit do not gain property rights over the services, they provide the technology to organize the networks. Car sharing providers like BMW's DriveNow or Daimler's Car2Go offer their own products. This allows the providers to retain property rights at the cost of individualization. Car sharing platform providers like Turo or Greenwheels waive property rights, and achieve higher levels of Individualization. Flinkster belongs to the German railway company Deutsche Bahn, offers a variety of cars from all major producers, and holds the property rights over all goods and services. Thus, Flinkster offers a mobility concept that comprises train rides and different cars that meet individual demands. A special case between car sharing platform providers and company bound car sharing is Getaround. Getaround offers a network for car sharing and like Turo or Greenwheels. However, network members who want to offer their vehicles have to install a special corporate software and pay monthly fees for it. Thereby, Getaround achieves at least a partial property right over the cars offered in the network. On the one hand, this software is part of the larger constituting technology that enables transactions in the activity system of Getaround. On the other hand, this software might also be part of their concept to capture value.

\section{Discussion and Conclusion}

The sharing economy has taken up speed and is spreading into B2C and $\mathrm{B} 2 \mathrm{~B}$ markets. Traditional strategic management cannot explain how value is created in the sharing economy. The sharing economy demands a new value creating perspective of (IT)technology. Long-linked and intensive technologies 
serve to create a basic offer, mediating technologies enhance internet access, but the sharing economy requires more for the control, organization, and distribution of physical goods over platforms: integrated networks' technologies serve to organize the networks of the involved parties and builds a fundament for value creation and capture in the sharing economy which still require the combination of different activities from the technologies and other activities that design the business model. Thus, web technology becomes a constituting technology. Therefore, we develop novel form of value configuration for the sharing economy moving beyond the three forms of Stabell [15] and by integrating the business model approach [30, 36]. Inspired from previous research and case examples we develop a model of the integrated value network. The integrated network requires web-based information technology that constitutes and links activities in a business model which connects the virtual and the real world. New ideas of content may base upon linkages of activities among multiple partners including customers, some of them performing services or goods in the real world. Case examples show that integrated networks may position their value creation on two dimensions that help positioning of the network: Standardization vs. Individualization of the content and particularism or centralization of ownership of the shared good causing different systems for governance including socioemotional interest of the providers. These novel two dimensions refer to the governance of business models that has strong relations to the ownership of real goods and the possibilities to shape design and as such novelty, maintenance, and positioning of the physical good, and or efficiency by more or less individualized solutions. Future integrated value networks, respectively focal firms create business models and platforms within these dimensions. More individualized content as well higher particularism of ownership require more complex systems for interactions and thus sets greater demands on the core technology, the IT.

We extend current research $[3,5,8]$ and emphasize that actual examples of the sharing economy are cases of business model innovation and demand established firms to rethink their way of doing business. Further, our line of reasoning is supported by research that considers IT among the strongest drivers of innovation $[5,44]$. We predict an even more dominant role for innovation through the combination of the sharing economy with artificial intelligence and virtual reality. We assume that this nexus will increasingly trigger R\&D processes and very novel forms of sharing, codevelopment, and co-production within real worlds and virtual worlds. Nonetheless, firms entering new business models in the sharing economy might unwittingly or deliberately cause a creative destruction of their own business models [5]. Previous examples show that especially young firms - entrants - have been successful in the sharing economy, while incumbents struggle to create value and have focused to acquire entrants and their value creation model [45].

Our paper uses theoretic considerations and caseexamples. One limitation is not having large sample data to test our model. We also do not show relations to firm performance. Future studies might use large sample or archival data for further developments and testing. Future research might also dig into the question what firms can develop success in the short run in their integrated networks and what conditions might help them in achieving a sustained success. This could possibly require greater constant changes to their business model

\section{References}

[1] J. Hamari, M. Sjöklint, and A. Ukkonen, "The sharing economy: Why people participate in collaborative consumption", Journal of the Association for Information Science and Technology, 2015.

[2] J. Oskam, and A. Boswijk, "Airbnb: the future of networked hospitality businesses", Journal of Tourism Futures, 2016, 2(1): pp. 22-42.

[3] B. Hartl, E. Hofmann, and E. Kirchler, "Do we need rules for "what's mine is yours"? Governance in collaborative consumption communities", Journal of Business Research, 2016, 69(8): pp. 2756-2763.

[4] M. Moehlmann, "Collaborative consumption: determinants of satisfaction and the likelihood of using a sharing economy option again", Journal of Consumer Behaviour, 2015, 14(3): pp. 193-207.

[5] R. Belk, "You are what you can access: Sharing and collaborative consumption online", Journal of Business Research, 2014, 67(8): pp. 1595-1600.

[6] F. Bardhi, and G.M. Eckhardt, "Access-based consumption: The case of car sharing", Journal of Consumer Research, 2012, 39(4): pp. 881-898.

[7] S. Wallsten, "The competitive effects of the sharing economy: how is Uber changing taxis?", Technology Policy Institute, 2015.

[8] B. Cohen, and J. Kietzmann, "Ride On! Mobility Business Models for the Sharing Economy", Organization \& Environment, 2014, 27(3): pp. 279-296.

[9] G. Zervas, D. Proserpio, and J. Byers, "The rise of the sharing economy: Estimating the impact of Airbnb on the hotel industry", Boston U. School of Management Research Paper, 2015(2013-16).

[10] J. Chan, N. Pun, and M. Selden, "The politics of global production: Apple, Foxconn and China's new working class", New Technology, Work and Employment, 2013, 28(2): pp. 100-115. 
[11] J. Lee, B. Bagheri, and H.-A. Kao, "A Cyber-Physical Systems architecture for Industry 4.0-based manufacturing systems", Manufacturing Letters, 2015, 3: pp. 18-23.

[12] M. Brettel, et al., "How virtualization, decentralization and network building change the manufacturing landscape: An Industry 4.0 Perspective", International Journal of Mechanical, Industrial Science and Engineering, 2014, 8(1): pp. 37-44.

[13] M. Porter, Competitive Advantage: Creating and Sustaining Superior Performance. 1985, New York: The Free Press.

[14] J. Barney, "Firm resources and sustained competitive advantage", Journal of Management, 1991, 17(1): pp. 99120.

[15] C.B. Stabell, and Ø.D. Fjeldstad, "Configuring value for competitive advantage: on chains, shops, and networks", Strategic Management Journal, 1998, 19(5): pp. 413-437.

[16] D. Laffey, and A. Gandy, "Applying Stabell and Fjeldstad's value configurations to E-commerce: A crosscase analysis of UK comparison websites", The Journal of Strategic Information Systems, 2009, 18(4): pp. 192-204.

[17] C. Zott, and R. Amit, "Designing your future business model: An activity system perspective", Long Range Planning, 2009, 43: pp. 216-226.

[18] Ø.D. Fjeldstad, et al., "The architecture of collaboration", Strategic Management Journal, 2012, 33(6): pp. 734-750.

[19] B. Carlsson, "The Digital Economy: what is new and what is not?", Structural Change and Economic Dynamics, 2004, 15(3): pp. 245-264.

[20] A. Afuah, "Redefining Firm Boundaries in the Face of the Internet: Are Firms Really Shrinking?", The Academy of Management Review, 2003, 28(1): pp. 34-53.

[21] M. Pohjola, "The New Economy: facts, impacts and policies", Information Economics and Policy, 2002, 14(2): pp. 133-144.

[22] M.E. Porter, "From Competitive Advantage to Corporate Strategy", Harvard Business Review, 1987, 65(3): pp. 43-59.

[23] M. Porter, "Towards a Dynamic Theory of Strategy", Strategic Management Journal, 1991, 12: pp. 95-117.

[24] E.T. Penrose, The theory of the growth of the firm. 1959, Oxford: Basil Blackwell.

[25] J.B. Barney, "Types of Competition and the Theory of Strategy: Toward an Integrative Framework", Academy of Management Review, 1986, Vol. 11(Nr. 4): pp. 791-800.

[26] J.D. Thompson, Organizations in Action: Social Science Bases of Administrative Theory. 1967, New York,: McGraw-Hill.

[27] J.F. Rayport, and J.J. Sviokla, "Exploiting the virtual value chain", Harvard business review, 1995, 73(6): pp. 7585 .

[28] D. Laffey, "Click trading: A case study of Moneynet", The Journal of Strategic Information Systems, 2009, 18(1): pp. 56-64.

[29] R. Amit, and C. Zott, "Creating value through business model innovation", MIT Sloan Management Review, 2012, 53(3): pp. 41.

[30] R. Amit, and C. Zott, "Value creation in e-business", Strategic management journal, 2001, 22(6-7): pp. 493-520.
[31] C. Zott, R. Amit, and L. Massa, "The Business Model: Recent Developments and Future Research", Journal of Management, 2011, 37(4): pp. 1019-1042.

[32] R.B. Bouncken, and V. Fredrich, "Good fences make good neighbors? Directions and safeguards in alliances on business model innovation", Journal of Business Research, 2016.

[33] S.M. Laudien, and B. Daxböck, "Business model innovation processes of average market players: a qualitative-empirical analysis", R\&D Management, 2016.

[34] C. Zott, and R. Amit, "Business Model Design: An Activity System Perspective", Long Range Planning, 2010, 43(2-3): pp. 216-226.

[35] B. Demil, et al., "Introduction to the SEJ Special Issue on Business Models: Business Models within the Domain of Strategic Entrepreneurship", Strategic Entrepreneurship Journal, 2015, 9(1): pp. 1-11.

[36] R. Amit, and C. Zott, "Business model innovation: Creating value in times of change", IESE Research Papers, 2010, D/870: pp. 1-15.

[37] S.M. Laudien, and B. Daxböck, "Path dependence as a barrier to business model change in manufacturing firms: insights from a multiple-case study", Journal of Business Economics, 2015: pp. 1-35.

[38] D.J. Teece, "Business Models, Business Strategy and Innovation", Long Range Planning, 2010, 43(2-3): pp. 172194.

[39] H. Chesbrough, "Business model innovation: it's not just about technology anymore", Strategy \& Leadership, 2007, 35(6): pp. 12-17.

[40] K.M. Eisenhardt, and M.E. Graebner, "Theory Building From Cases: Opportunities And Challenges", Academy of Management Journal, 2007, 50(1): pp. 25-32.

[41] R.K. Yin, Case study research: Design and methods. 4th ed. ed. 2009, Thousand Oaks, CA: Sage publications.

[42] K.M. Eisenhardt, "Agency theory: An assessment and review", Academy of management review, 1989, 14(1): pp. 57-74.

[43] M. Ram, and K. Trehan, "Critical by design: enacting critical action learning in a small business context", Action Learning: Research and Practice, 2009, 6(3): pp. 305-318.

[44] O. Gassmann, E. Enkel, and H. Chesbrough, "The future of open innovation", R\&D Management, 2010, 40(3): pp. 213-221.

[45] C. Markides, and C.D. Charitou, "Competing with dual business models: A contingency approach", The Academy of Management Executive, 2004, 18(3): pp. 22-36. 